\title{
Penguatan Strategi Pemasaran sebagai Upaya Pertahanan Usaha Mikro Milik Warga
}

\author{
Shifa Rahmani, Maman Rosama KM \\ Program Studi Ekonomi Syariah, STAI DR. KH. EZ. Muttaqien \\ Email: shifarahmani980@gmail.com
}

DOI: https://doi.org/10.52593/svs.01.2.05

Naskah diterima: 10 Juli 2021, direvisi: 27 Juli 2021, disetujui: 27 Juli 2021

\begin{tabular}{l} 
Abstract \\
\hline Keywords: \\
Micro business - \\
Covid-19 - Marketing \\
Strategy
\end{tabular}

The impact of the Covid-19 pandemic has affected all sectors without exception the economic sector, all existing conditions are forced to change and must adjust if they do not do so they will be left behind. This is what is experienced by micro entrepreneurs, their opinion continues to decrease drastically due to this phenomenon. If it continues without changes and defense efforts, there will be no hope for its business to survive let alone develop. Not to mention matters relating to fulfilling their daily necessities, which they only rely on from the net income of their business. Changes need to be made, one of which is through coaching community owners of micro businesses, by providing material content that focuses on implementing effective marketing strategies adapted to current conditions. Even though they have received capital assistance from the Government, this must still be done in order to increase the capacity of micro business owners so that they can independently maintain their businesses and even develop them, so that their daily needs can be met which in turn can help create welfare for micro business owners

\begin{tabular}{ll} 
Abstrak & Dampak dari pandemi Covid-19 membuat semua sektor terdampak tanpa \\
\hline Kata kunci: & terkecuali sektor ekonomi, semua kondisi yang ada terpaksa untuk dirubah dan \\
19-Strategi & mesti menyesuaikan jika tidak melakukannya maka akan tertinggal. Hal ini \\
Pemasaran & yang dialami para pengusaha mikro, pendapat mereka terus menerus menurun \\
& secara drastis akibat fenomena ini. Jika terus dibiarkan tanpa dilakukan \\
& perubahan dan usaha pertahanan makatidak akan ada harapan bagi usahanya \\
& untuk bertahan apalagi berkembang. Belum lagi urusan yang menyangkut \\
pemenuhan kebutuhan hidup, yang mana mereka hanya mengandalkan dari & hasil pendapatan bersih usahanya. Perubahan perlu dilakukan salah satunya \\
& melalui pembinaan terhadapa warga pemilik usaha mikro, dengan memberikan \\
& muatan materi yang berfokus pada penerapan strategi pemasaran yang efektif \\
disesuaikan dengan kondisi saat ini. Meskipun mereka telah mendapatkan \\
bantuan modal dari Pemerintah hal ini tetap harus dilakukan guna menambah \\
kapasitas para pemilik usaha mikro agar dapat secara mandiri \\
mempertahankan usahanya bahkan bisa mengembangkannya, sehingga dapat \\
terpenuhi kebutuhan hidupnya yang pada akhirnya dapat membantu \\
menciptakan kesejahteraan terhadap para pemilik usaha mikro
\end{tabular}

\section{PENDAHULUAN}

Sejak terjadinya kasus pertama virus corona di Indonesia yang diumumkan pada bulan Maret 2020 hingga kini masih terdapat peningkatan kasus positif disetiap harinya. Hal ini sangat mempengaruhi laju perekonomian di Indonesia dan secara otomatis juga berpengaruh terhadap daya beli masyarakat pada suatu barang atau jasa yang dirasa tidak termasuk kedalam kebutuhan primer. Selain daripada itu banyak pula para pekerja yang di PHK dan masih banyak lagi orang-orang yang terkena dampak dari fenomena ini. Terkait dalam fenomena ini yang perlu sangat diperhatikan adalah mengenai kesejahteraan masyarakat. 
Banyak bantuan-bantuan sosial yang diberikan oleh pemerintah, salah satunya adalah pemerintah memberikan bantuan BPUM (Banpres Produktif untuk Usaha Mikro) yang merupakan bantuan yang diberikan kepada para pelaku usaha kecil menengah mikro (UMKM) di Indonesia, besarannya Rp. 2.400 .000 dan diberikan dalam sekali pencairan. Disamping bantuan yang telah diberikan masyarakat diharapkan secara mandiri dapat mengembangkan usahanya dengan bantuan tersebut dan tentu saja ada beberapa hal yang perlu mereka lakukan agar bantuan yang didapatkan bisa dipakai secara efektif dan efisien.

Di Kelurahan Nagri Tengah Kecamatan Purwakarta terdapat beberapa warga yang mendapatkan bantuan tersebut diantara banyaknya pendaftar yang mengikuti proses seleksi penerima BPUM. Setelah dilakukan wawancara terhadap beberapa warga, mereka mengaku belum adanya kegiatan yang diadakan oleh pemerintah daerah setempat untuk memberikan edukasi secara khusus mengenai pengembangan usaha kecil milik warga sekitar guna meningkatkan kesejahteraan warganya dikarnakan situasi dan kondisi yang terjadi saat ini. Berikut adalah data warga pemilik usaha mikro yang telah menerima BPUM.

Tabel 1. Warga Pemilik Usaha Mikro

\begin{tabular}{llc}
\hline \multicolumn{1}{c}{ Nama } & \multicolumn{1}{c}{ Pekerjaan } & Wilayah RT \\
\hline Ibu Anita & Pedagang kue basah & 039 \\
Bapak Sofian & Pedagang Roti Kukus & 038 \\
Ibu Lilis & Pemilik warung makanan ringan & 041 \\
Bapa Endang B & Pedagang makanan ikan \& alat pemancingan & 041 \\
Ibu Nani & Pemilik warung makanan ringan & 039 \\
Ibu Anita & Pedagang kue basah & 039 \\
\hline
\end{tabular}

Suntikan dana BPUM ke Kelurahan Nagritengah ini perlu dimanfaatkan sesuai dengan tujuan pemberian bantuan ini yaitu agar pelaku usaha mikro ini dapat bertahan dalam menghadapi kesulitan ekonomi pada masa Pandemi Covid-19. Pendekatan yang digunakan untuk mengetahui ketahanan para pelaku usaha tersebut adalah Model 5M, yaitu faktorfaktor produksi utama yang dibutuhkan agar perusahaan dapat beroperasi secara maksimal, meliputi: man, money, material, machines, method. Pendekatan ini diadaptasi untuk mengetahui kondisi pelaku usaha berskala mikro yang telah mendapat bantuan BPUM. Adapun batasannya adalah sebagai berikut:

1. Man (Manusia), merujuk pada pelaku usaha yang mendapat bantuan BPUM.

2. Money (Uang/Modal) merujuk pada tambahan modal dari pemerintah sebagai subsidi untuk mempertahankan kesinambungan usahanya.

3. Materials (Bahan baku), merujuk pada bahan baku sebagai unsur utama untuk diolah menjadi produk akhir untuk diserahkan kepada konsumen.

4. Machines (Mesin), merujuk pada fasilitas/alat penunjang kegiatan perusahaan baik operasional maupun nonoprasional untuk mengolah bahan baku menjadi barang yang siap dikonsumsi.

5. Method (Metode/Prosedur), merujuk pada metode/prosedur maupun pengetahuan sebagai panduan pelaksanaan kegiatan usaha. 
Hasil observasi dan wawancara dengan pihak-pihak terkait, menunjukkan bahwa bagian terlemah dari kelima faktor produksi tersebut adalah butir ke lima, yaitu method, dalam pengertian bahwa para pelaku usaha mikro ini belum memiliki bekal pengahuan yang memadai untuk mengatasi permasalahan yang mereka hadapi. Selain dari tingkat pendidikannya yang tergolong rendah, juga disebabkan oleh belum adanya program pembinaan dari Pemerintah Daerah. Sisi inilah yang menjadi fokus kami dalam melaksanakan PBP (Pengabdian Berbasis Penelitian), yaitu dengan memberi sumbangan pemikiran dalam rangka mengembangkan usaha UMKM, setidaknya dapat bertahan pada situasi yang sulit ini.

Sebelum ditemukan formula apa yang sebaiknya diterapkan pada pengembangan usaha ini, terlebih dahulu perlu dilakukan analisis transektoral atau penelusuran untuk mengetahui kondisi dan permasalahan sektor-sektor yang ada di wilayah tersebut. Untuk mengetahui hal itu maka kami buat batasan sebagai berikut:

Tabel 2. Transectoral

\begin{tabular}{ll}
\hline TOPIK/ASPEK & Kondisi para pengusaha kecil di tengah Pandemi Covid-19. \\
\hline MASALAH & - Penurunan pendapatan secara drastis dan terus-menerus. \\
& - Persaingan semakin tinggi. \\
TUJUAN & Pertahanan usaha kecil, baik sebagai akibat dari adanya \\
& Pandemi Covid-19 maupun dalam kondisi normal. \\
& $\begin{array}{l}\text { - Kembali meningkatnya pendapatan usaha. } \\
\text { PRATINDAKAN }\end{array}$ \\
RENCANA TINDAKAN & $\begin{array}{l}\text { Aktivitas usaha berjalan secara tradisional. } \\
\text { BARU }\end{array}$ \\
& $\begin{array}{l}\text { didalamnya dengan saling bertukan pikiran dan gagasan } \\
\text { seputar "penguatan strategi pemasaran di tengah pandemi } \\
\text { Covid-19" }\end{array}$ \\
\hline
\end{tabular}

Terhitung setelah satu minggu sejak dimulainya pelaksanaan PBP dilakukanlah kegiatan wawancara kepada aparat pemerintahan desa setempat, serta RW, RT, dan warga agar dapat ditemukan permasalahan yang ditengah dihadapi dan kemudian bisa dibantu penyelesaian masalahnya.

Situasi Kecamatan Purwakarta yang saat ini sangat tidak memungkinkan untuk melakukan kegiatan usaha seperti pada keadaan normal karna telah memasuki zona merah penyebaran kasus positif covid-19. Hal ini membuat beberapa kegiatan untuk pemberdayaan masyarakat dibidang ekonomi menjadi terhambat. Oleh karna fenomena ini, kegiatan yang dibutuhkan oleh warga pemilik usaha kecil tetap harus dilakukan guna mempertahankan dan mengembangkan usaha milik warga agar terciptanya kesejahteraan bersama serta bangkitnya usaha mikro, kecil dan menengah.

Tantangan yang tengah dihadapi para pemilik usaha kecil ini adalah mulai menurunnya permintaan terhadap produk yang ditawarkan. Penyebab utamanya karna turunnya daya beli masyarakat serta barang yang ditawarkan tidak tergolong ke dalam kebutuhan pokok, sehingga peminatnya berkurang. Tingkat penurunan penjualan bisa mencapai $50 \%$ bahkan bisa lebih dari itu, hal ini tentu menjadi sangat penting untuk segera diatasi. 
Mereka sangat membutuhkan pemasukan dari hasil usahanya untuk pemenuhan kebutuhan hidup sehari-hari, maka dari itu perlu dilakukan tindakan agar dapat membantu para pelaku usaha untuk tetap bertahan bahkan bisa mengembangkan usahanya. Pada hemat kami, untuk mengatasi permasalahan ini mereka perlu dibekali dengan pengetahuan dan pemahaman tentang strategi pemasaran yang efektif dan efisien sesuai kapasitas usaha yang mereka jalani. Pada saat yang bersamaan kami berkolaborasi dengan para pemilik usaha kecil agar teori yang kami angkat dapat diimplementasikan langsung pada kegiatan usahanya.

Setelah melakukan penelusuran, peneliti juga membutuhkan data yang meliputi tenaga kerja, kualitas angkatan kerja dan mata pencaharian pokok sebagai data primer yang digunakan peneliti. Berikut data yang didapatkan dari hasil wawancara dengan Kasi Kesejahteraan Sosial.

Tabel 3. Tenaga Kerja

\begin{tabular}{lrr}
\hline \multicolumn{1}{c}{ Tenaga Kerja } & Laki-laki & perempuan \\
\hline Penduduk 18-56 Tahun & 140 orang & 138 orang \\
Penduduk 18-56 Tahun yang bekerja & 561 orang & 520 orang \\
Penduduk 18-56 Tahun yang belum atau tidak bekerja & 520 orang & 419 orang \\
Penduduk Usia 0-6 Tahun & 217 orang & 201 orang \\
Penduduk masih sekolah 7-18 tahun & 512 orang & 519 orang \\
Penduduk usia 56 tahun ke atas & 217 orang & 198 orang \\
Angkatan kerja & 450 orang & 581 orang \\
Jumlah & $\mathbf{2 . 6 1 7 ~ o r a n g}$ & $\mathbf{2 . 5 7 6 ~ o r a n g}$ \\
\hline
\end{tabular}

Tabel 4. Kualitas Angkatan Kerja

\begin{tabular}{lrr}
\hline \multicolumn{1}{c}{ Angkatan Kerja } & Laki-laki & perempuan \\
\hline Penduduk usia 18-56 tahun yang tidak tamat SD & 47 orang & 51 orang \\
Penduduk usia 18-56 tahun yang tamat SD & 52 orang & 57 orang \\
Penduduk usia 18-56 tahun yang tamat SLTP & 107 orang & 1.552 orang \\
Penduduk usia 18-56 tahun yang tamat SLTA & 275 orang & 281 orang \\
Penduduk usia 18-56 tahun yang tamat Perguruan Tinggi & 137 orang & 141 orang \\
Jumlah & $\mathbf{6 1 8 ~ o r a n g}$ & $\mathbf{2 . 0 8 2}$ orang \\
\hline
\end{tabular}


Tabel 5. Mata Pencaharian Pokok

\begin{tabular}{|c|c|c|}
\hline Jenis Pekerjaan & Laki-laki & Perempuan \\
\hline Petani & 6 orang & 2 orang \\
\hline Buruh Migran & 24 orang & 19 orang \\
\hline Pegawai Negri Sipil & 110 orang & 118 orang \\
\hline Peternak & 5 orang & 2 orang \\
\hline Montir & 11 orang & 0 orang \\
\hline Dokter Swasta & 3 orang & 2 orang \\
\hline Perawat Swasta & 10 orang & 11 orang \\
\hline Bidan Swasta & 0 orang & 5 orang \\
\hline TNI & 24 orang & 6 orang \\
\hline POLRI & 27 orang & 15 orang \\
\hline Pegusaha kecil, menengah, dan besar & 21 orang & 23 orang \\
\hline Guru Swasta & 16 orang & 12 orang \\
\hline Dosen Swasta & 12 orang & 17 orang \\
\hline Seniman/artis & 3 orang & 1 orang \\
\hline Pedagang Keliling & 51 orang & 27 orang \\
\hline Pembantu rumah tangga & 12 orang & 17 orang \\
\hline Pengacara & 2 orang & 1 orang \\
\hline Notaris & 4 orang & 3 orang \\
\hline Arsitektur/Desainer & 2 orang & 0 orang \\
\hline Karyawan perusahaan pemerintah & 5 orang & 6 orang \\
\hline Wiraswasta & 57 orang & 52 orang \\
\hline Purnawirawan/Pensiunan & 15 orang & 3 orang \\
\hline Pengrajin industri rumah tangga lainnya & 4 orang & 7 orang \\
\hline Jasa Konsultasi Manajemen dan Teknis & 7 orang & 2 orang \\
\hline Jumlah Total & 782 orang & \\
\hline
\end{tabular}


Data diatas digunakan sebagai salah satu dasar pertimbangan penelitian yang dilakukan melihat dari kebutuhan warga yang paling terdampak, maka mata pencaharian pokok pengusaha kecil yang menjadi fokus penelitian.

Pada awal bulan Oktober Pemerintah Pusat telah memberikan bantuan BPUM untuk UMKM dalam rangka Pemulihan Ekonomi Nasional (PEN) akibat pandemi Covid-19 di Indonesia, para pemilik usaha mikro, kecil dan menengah tentu menyambut dengan sangat baik bantuan ini, namun yang mereka keluhkan adalah mereka belum memiliki strategi khusus apalagi yang mesti dilakukan untuk peningkatan penjualan barang atau jasa mereka melalui bantuan yang telah diberikan. Inilah yang menjadi awal agar permasalahan ini cepat ditindaklanjuti agar usaha kecil milik warga dapat bertahan ditengah kondisi seperti ini.

Adapun tujuan dari Pengabdian Berbasis Penelitian (PBP) yang dilakukan mahasiswa yang selanjutnya disebut Mahasiswa Pengabdi dan Peneliti (MPP) diantaranya, adalah:

1. Saling berbagi pengetahuan mengenai "pemasaran" yang meliputi teori dan prakteknya.

2. Dapat membuat berbagai strategi pemasaran agar usaha yang dimiliki dapat bertahan serta dapat menaikan tingkat penjualan barang yang ditawarkan.

Dalam hal ini peneliti berperan mencari informasi, fakta, dan data mengenai warga yang memiliki usaha kecil yang kemudian menjadi langkah awal untuk pembentukan tidakan yang mesti diambil untuk dapat membantu permasalahan yang ada, yang kemudian dapat diimplementasikan langsung oleh warga tersebut kedalam usahanya. Tujuan diatas merupakan tolok ukur untuk membuat suatu kegiatan baru yang sebelumnya belum pernah ada dan dilakukan ditengah warga setempat yang memiliki usaha kecil, maka dari itu penting untuk segera dilakukan suatu kegiatan yang dapat memenuhi kebutuhan warga akan strategi apa yang mesti dilakukan untuk peningkatan pemasaran usahanya.

Pada situasi seperti ini para pemilik usaha kecil perlu memiliki berbagai strategi untuk dapat mempertahankan usahanya, melihat keadaan yang terjadi setelah kurang lebih delapan bulan yang lalu perlu adanya suatu perubahan pada kegiatan pemasaran yang tentunya mesti menyesuaikan dengan aturan yang ada, dimana kegiatan usaha tetap bisa dijalankan. Sebelum melakukan perubahan terhadap kegiatan pemasaran, kita perlu memahami terlebih dahulu teori dalam buku "Studi Kelayakan Bisnis" mengenai "Kajian Aspek Pasar dan Pemasaran".

Pasar secara sederhana bisa diartikan sebagai tempat bertemunya para penjual dan pembeli untuk melakukan transaksi, artinya bahwa pasar memiliki lokasi atau tempat tertentu sehingga memungkinkan terjadinya pembeli dan penjual bertemu untuk melakukan transaksi jual beli. Namun pada kenyataannya pasar dapat diartikan lebih luas, artinya pembeli dan penjual tidak harus bertemu disuatu tempat untuk melakukan transaksi, tetapi cukup melalui penggunaan sarana elektronik dan media lain seperti telepon, faksimili atau internet. Hal ini menunjukkan bahwa pasar memiliki lokasi atau tempat tertentu sehingga pembeli dan penjual bertemu untuk melakukan transaksi. Akan tetapi, pasar dapat terjadi disembarang tempat melalui berbagai sarana prasana. (Purwadi \& Hidayat, 2016: 67)

Sedangkan pengertian Pemasaran seperti yang dikemukakan oleh Philip Kotler adalah: "Suatu proses sosial dan manajerial dengan mana individu dan kelompok memperoleh apa yang mereka butuhkan dan inginkan dengan cara menciptakan serta mempertukarkan produk dan nilai dengan pihak lain". Dengan demikian, pemasaran diartikan sebagai upaya 
menciptakan dan menjual produk kepada berbagai pihak. Pemasaran berusaha menciptakan dan melakukan pertukaran produk baik barang maupun jasa kepada konsumen di pasar. Akan sangat berbahaya jika penciptaan produk tidak didasarkan kepada keinginan dan kebutuhan konsumen. Konsumen yang menginginkan dan membutuhkan produk adalah perorangan atau kelompok. Strategi pemasaran dapat dilakukan melalui Marketing Mix. (Purwadi \& Hidayat, 2016: 69)

Ditengah Pandemi Covid-19 yang dialami di Indonesia khususnya, banyak menurunkan omset penjualan UMKM. Berkurangnya jumlah konsumen dibeberapa sektor dan industri menuntut pelaku UMKM untuk dapat memasarkan produk secara maksimal dan berfikir kreatif dan inovatif. Penggunaan internet pada masa pandemik Covid-19 ini sudah seperti keharusan termasuk dalam menjalankan bisnis dan salah satu upaya dalam memasakan produk yang dapat di adopsi oleh pelaku UMKM adalah dengan melakukan digital marketing. Era digital yang berkembang pesat saat ini tidak mungkin untuk dihindari. Pakar pemasaran Yuswohadi mengungkapkan bahwa jika ingin bertahan, maka pelaku UMKM harus mampu memaksimalkan manfaat perkembangan digital.

Digital marketing adalah adalah kegiatan promosi dan pencarian pasar melalui media digital secara online dengan memanfaatkan berbagai sarana misalnya jejaring sosial. Cara pemasaran secara digital yang sering dimanfaatkan oleh pelaku usaha adalah dengan menggunakan media sosial seperti memasarkan produk melalui instagram, facebook, twitter dan masih banyak lagi. Selain itu pemasaran digital juga bisa dilakukan pada e-commerce dan banyak media lainnya. Perkembangan teknologi yang semakin pesat juga menjadikan digital marketing harus dapat dipahami dan dipelajari oleh UMKM.

Penelitian menyatakan, digital marketing berpengaruh positif dan signifikan dalam peningkatan kinerja penjualan UMKM. 70\% Pengusaha kreatif mengatakan digital marketing akan menjadi platform komunikasi utama dalam pemasaran, dan offline store akan menjadi pelengkap, dikarenakan kemudahan dan kemampuan digital marketing dalam menjangkau lebih banyak konsumen. Hal ini juga sejalan dengan penelitian yang dilakukan dan menyatakan bahwa pelaku usaha harus menumbuhkan keberanian dalam mencoba hal baru seperti digital pemasaran untuk dapat terus mengembangkan usahanya. Pelaku UMKM juga dapat memulai dengan membuat sosial media dan secara rutin melakukan promosi sehingga akan semakin percaya diri dan mengasah kreatifitas dalam pemasaran. (Laura "Strategi Bertahan UMKM di Tengah Pandemi Covid-19” Jurnal, Riau, Jurnal Akuntansi \& Ekonomika, Vol 10 No. 1, Juni 2020, 94.)

Berdasarkan beberapa teori diatas yang diambil dari beberapa sumber dan referensi bacaan sangat relevan dengan situasi dan kondisi yang terjadi saat ini kepada para pelaku usaha kecil, yang nantinya ini bisa menjadi acuan untuk membuat perubahan baru terhadap strategi pemasaran yang selama ini hanya dilakukan secara konvensional saja. 


\section{METODE}

Penelitian kualitatif merupakan metode-metode untuk mengeksplorasi dan memahami makna yang oleh sejumlah individu atau sekelompok orang dianggap berasal dari masalah sosial atau kemanusiaan. Proses penelitian kualitatif ini melibatkan upaya-upaya penting, seperti mengajukan pertanyaan-pertanyaan dan prosedur-prosedur, mengumpulkan data yang spesifik dari para partisipan, menganalisis data secara induktif mulai dari tema-tema yang khusus ke tema-tema umum, dan menafsirkan makna data. Laporan akhir penelitian ini memiliki struktur atau kerangka yang fleksibel. Siapa pun yang terlibat dalam bentuk penelitian ini harus menerapkan cara pandang penelitian yang bergaya induktif, berfokus terhadap makna individual, dan menerjemahkan kompleksitas suatu persoalan (Creswell, 2010:4). Sumber data yang digunakan adalah data primer yang didapat melalui hasil wawancara langsung dan data sekunder yang didapat dengan data yang dikumpulkan, diolah, dan disajikan oleh orang lain melalui jurnal ilmiah dan buku terkait usaha mikro, kecil, dan menengah (UMKM). Setelah melakukan wawancara partisipatif juga mengkaji data dan informasi yang ada dilapangan, kemudian dihubungkan dengan teori yang nantinya akan dijadikan sebagai hasil daripada hasil penelitian yang dapat dimanfaatkan atau diadopsi oleh para pemilik usaha mikro.

Subjek penelitian diambil dari beberapa orang warga yang memiliki usaha kecil dan telah mendapatkan bantuan BPUM. Disini MPP mengambil dua orang warga dari tiga wilayah RT yang berbeda dalam satu RW. Kegiatan penelitian tindakan partisipatif ini dilakukan secara langsung mendatangi rumah warga yang menjadi subjek penelitian, dilakukan melaui komunikasi dua arah antara warga dan MPP. Kegiatan ini bertempat di Kelurahan Nagri Tengah, Kecamatan Purwakarta, Kabupaten Purwakarta RW 07, RT 038, 039, dan 041. Waktu penelitian dilaksanakan selama bulan November 2020

\section{HASIL DAN PEMBAHASAN}

Pengabdian kepada masyarakat adalah usaha untuk menyebarluaskan ilmu pengetahuan, teknologi, dan seni kepada masyarakat. Dalam hal ini peneliti telah melakukan pengabdian kepada masyarakat yang sifatnya menyebarluaskan ilmu pengetahuan terkait perekonomian yang berfokus pada materi pemasaran melalui strategi pemasaran yang efektif dimasa sekarang.

Kegiatan dilakukan dengan kunjungan langsung kerumah-rumah warga pemilik usaha mikro untuk melakukan rencana kegiatan yang telah dicanangkan, indikator pencapaian tujuan kegiatan ini adalah bagaimana agar para pemilik usaha mikro ini dapat melakukan pertahanan dengan cara mengubah pola strategi pemasarannya agar dapat berhasil melewati masa sulit ditengah pandemi Covid-19. Tolak ukur keberhasilan dilihat dari meningkatnya volume penjualan. Keunggulan dalam kegiatan ini dapat memberikan wawasan lebih kepada warga pemilik usaha mikro, begitupula dengan peneliti. Bisa saling bertukar pikiran dan gagasan mengenai strategi pemasaran yang paling pas untuk diterapkan pada saat ini. Terlepas dari itu karena kegiatan ini terbatas oleh waktu, maka hasilnya akan kurang maksimal dan harus dilakukan secara berkala agar apa yang disampaikan bisa terserap untuk kemudian bisa diimplementasikan pada kegiatan usahanya. Pada pelaksanaan peneliti mendapat beberapa kendala karna mesti menyesuaikan dengan kondisi warga yang memiliki jadwal kegiatan yang berbeda satu dengan lainnya. Hasil dalam Pengabdian Berbasis Penelitian (PBP), peneliti telah membuat muatan materi khusus yang disampaikan kepada 
warga pemilik usaha mikro dengan bentuk kegiatan pembinaan. Materi yang dibuat sangat ringan dan sederhana agar mudah untuk dipahami dan diaplikasikan langsung oleh warga terhadap kegiatan usahanya.

Muatan materi berfokus hanya kepada perubahan dalam strategi pemasaran yang dilakukan melalui bauran pemasaran (Marketing mix). Peneliti mengambil teori bauran pemasaran untuk dijadikan muatan materi dari buku yang berjudul "Studi Kelayakan Bisnis" yang ditulis oleh Dr. Dedi Purwadi E.S., M.Bus \& Drs. Nurdin Hidayat, M.M., M,Si. Tahun 2016. Bauran pemasaran ini ada 4, yakni sebagai berikut:

1. Produk (Product)

Produk menurut Philip Kotler adalah: "sesuatu yang dapat ditawarkan ke pasar untuk mendapatkan perhatian untuk dibeli, untuk digunakan atau dikonsumsi yang dapat memenuhi keinginan dan kebutuhan".

Dalam hal ini pembahasan yang diberikan berfokus pada pengembangan produk, meliputi:

a. Produk yang ditawarkan harus memberikan manfaat dasar bagi konsumen.

b. Produk yang ditawarkan harus memiliki kualitas dan kuantitas.

c. Produk yang ditawarkan harus memberikan kepuasan lebih tinggi melalui pengembangan produk tambahan bagi konsumen seperti layanan antar.

2. Harga (Price)

Harga merupakan salah satu aspek penting dalam kegiatan marketing mix. Penentuan harga menjadi sangat penting, hal ini dikarenakan harga merupakan salah satu penyebab laku tidaknya produk.

Pelaku usaha harus menentukan harga jual minimum bagi konsumen. Harga minimum ini dipengaruhi beberapa faktor antaralain:

a. Produk harus memiliki nilai jual yang bersaing dengan pelaku usaha lain yang sejenis.

b. Harga yang ditetapkan pelaku harus dapat dijangkau oleh masyarakat khsusnya konsumen yang dijadikan sasaran pembeli potensial.

c. Harga produk tidak harus memiliki tingkat keuntungan yang tinggi, hal ini terkait perputaran usaha khususnya dengan memiliki modal terbatas.

3. Distribusi (Place)

Penentuan lokasi beserta sarana dan prasarana pendukung menjadi sangat penting. Hal ini dilakukan agar konsumen mudah menjangkau setiap lokasi yang ada. Hal-hal yang perlu diperhatikan dalam penentuan lokasi sebagai berikut:

a. Dekat dengan lokasi perumahan atau masyarakat.

b. Dekat dengan lokasi pasar.

c. Mempertimbangkan pesaing yang ada disuatu lokasi.

d. Sarana dan prasarana.

4. Promosi (Promotion)

Promosi adalah proses pengenalan produk kepada konsumen. Proses ini dilakukan dalam usaha dengan berbagai cara guna meningkatkan penjualan. Tujuan promosi adalah meningkatkan penjualan atau jumlah pelanggan, bagi pelaku usaha promosi yang dapat dilakukan melalui:

a. Pemberian harga khusus atau potongan harga atas produk tertentu.

b. Promosi dan penjualan lainnya.

Analisis Strategi Pemasaran menggunakan matriks SWOT sebagai berikut: 


\begin{tabular}{|c|c|c|}
\hline EFAS & $\begin{array}{l}\text { Strenghts }(\mathrm{S}) \\
\text { - } \quad \text { Lokasi Strategis } \\
\text { - } \quad \text { Harga yang bersaing } \\
\text { - } \quad \text { Kualitas produk }\end{array}$ & $\begin{array}{l}\text { Weaknesses (W) } \\
\text { - Kurangnya modal } \\
\text { usaha } \\
\text { - Metode penjualan } \\
\text { dengan cara lama }\end{array}$ \\
\hline $\begin{array}{l}\text { Opportunities (0) } \\
\text { - Kompetitor } \\
\text { - Pola perilaku \& } \\
\text { kebutuhan } \\
\text { masyarakat } \\
\text { semakin } \\
\text { berkembang }\end{array}$ & $\begin{array}{l}\text { Strategi SO } \\
\text { - } \begin{array}{l}\text { Membuat harga yang } \\
\text { terjangkau }\end{array} \\
\text { - Memberikan diskon khusus } \\
\text { pada pelanggan loyal }\end{array}$ & 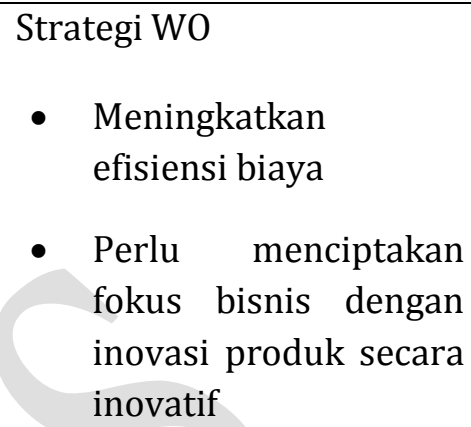 \\
\hline $\begin{array}{l}\text { Threats (T) } \\
\text { - Perkembangan } \\
\text { Teknologi } \\
\text { - Munculnya pesaing } \\
\text { baru } \\
\text { - Mahalnya barang } \\
\text { baku }\end{array}$ & $\begin{array}{l}\text { Strategi ST } \\
\text { - mengembangkan daya } \\
\text { saing } \\
\text { - } \quad \begin{array}{l}\text { Meningkatkan } \\
\text { pelayanan pada pelanggan }\end{array}\end{array}$ & $\begin{array}{l}\text { Strategi WT } \\
\text { - Penggunaan media } \\
\text { sosial sebagai media } \\
\text { promosi \& penjualan } \\
\text { - Menjalin hubungan } \\
\text { baik dengan } \\
\text { pelanggan }\end{array}$ \\
\hline
\end{tabular}

Matriks SWOT pada gambar tersebut diatas, dihasilkan empat alternatif strategis yang dapat diambil oleh para pemilik usaha kecil dalam menghadapi persaingan yang semakin kompetitif, yaitu sebagai berikut:

\section{Strategi Streght-Opportunities}

Kondisi ini menjadi kondisi yang diharapkan oleh para pengusaha karena kekuatan yang dimiliki oleh seorang pengusaha akan dipakai untuk segala kesempatan yang ada, sehingga dapat bersaing dengan pengusaha lain yang sejenis. Adapun beberapa kekuatan para pengusaha kecil di Kelurahan Nagri Tengah RW 07 RT 038, 039, 041 dalam memanfaatkan kesempatan yang ada:

a. Harga yang Terjangkau

Strategi harga merupakan salah satu strategi yang diterapkan oleh pengusaha, dalam menerapkan strategi bersaingnya untuk menghadapi persaingan yang ketat. Terciptanya harga yang bersaing pada para usaha kecil milik warga dengan menerapkan harga yang lebih murah akan lebih menarik konsumen. Terlepas dari itu kualitas produk harus tetap dipertahankan agar cita rasanya tidak berubah.

b. Diskon untuk Pelanggan 
Penerapan diskon juga bisa dijadikan sebagai salah satu alternatif yang bisa dilakukan untuk para pelanggan yang loyal supaya lebih merasa puas saat membeli produk untuk kesekian kalinya.

\section{Strategi Weaknesses-Opportunities}

Strategi ini ditetapkan berdasarkan pemanfaatan peluang yang ada dengan meminimalisir kelemahan yang dimiliki.

a. Meningkatkan Efisiensi Biaya

Pemilik usaha menggunakan modal yang berasal dari dana sendiri dan bantuan modal yang diberikan oleh Pemerintah dengan jumlah yang terbatas. Maka dari itu pemilik usaha harus melakukan efisiensi biaya agar para pemilik usaha bisa tetap memenuhi kebutuhan operasional usahanya.

b. Inovasi Produk secara inovatif

Pemilik usaha mesti membuat inovasi produk secara inovatif agar bisa terus menyesuaikan dengan kebutuhan konsumen dan tidak terkesan monoton produknya, ini juga bisa membantu untuk meningkatkan penjualan.

\section{Strategi Strenghts-Treat}

Strategi ini dimanfaatkan dengan menggunakan kekuatan yang dimiliki untuk mengatasi ancaman yang ada.

a. Mengembangkan Daya Saing

Suatu usaha yang memiliki daya saing adalah bila pelanggannya memperoleh kesan bahwa produknya lebih baik daripada produk pesaing. Pemilik usaha kecil menciptakan kesan ini dengan menjajakan produk yang memiliki kualitas baik dan cita rasa yang lebih enak dibanding dengan yang lain, sehingga dapat meningkatkan daya saing.

b. Meningkatkan Pelayanan pada Pelanggan

Pelayanan yang dilakukan oleh para pengusaha kecil sudah cukup baik, akan tetapi perlu ditingkatkan lagi dengan menjaga loyalitas pelanggan dan kenyamanan pelanggan.

\section{Strategi Weaknesses- Treat}

Strategi ini dilakukan agar meminimalisir kelemahan yang ada, serta menghindari ancaman. Dalam situasi dan kondisi yang terjadi saat ini menuntut para pemilik usaha kecil untuk berbenah diri agar tidak terjadi gulung tikar.

a. Media Sosial Sebagai Media Promosi \& Penjualan

Pada kondisi pandemi Covid-19 ini alternatif menggunakan media sosial adalah salah satu jalan yang paling efektif untuk dijadikan media promosi \& penjualan, dengan cara melakukan promosi gencar melalui aplikasi WhatsApp, Facebook, dan Instagram juga menggunakan Aplikasi Go-food atau Grab-food. Selain promosi yang dilakukan bisa lebih gencar dalam waktu singkat cara ini bisa sangat efektif untuk meningkatkan penjualan.

b. Menjalin Hubungan Baik dengan Pelanggan

Pelanggan merupakan aset terpenting bagi seorang pemilik usaha, oleh karena itu setiap pelayanan yang diberikan haruslah pelayanan terbaik bagi semua pelanggannya. 
Dengan adanya upaya penguatan strategi pemasaran bagi usaha kecil ini dapat membantu meningkatkan pendapatan usaha dan setidaknya usaha yang dimiliki dapat bertahan ditengah kondisi krisis seperti saat ini. Para pemilik usaha kecil juga bisa menyesuaikan perkembangan pemasaran secara digital dengan memanfaatkan media yang ada. Selain itu konsumen juga mendapatkan kemudahan transaksi karna tidak perlu keluar rumah untuk membeli barang yang diinginkan. Bila para pemilik usaha tidak mengikuti perkembangan yang ada dan hanya tertuju pada kegiatan penjualan secara tradisional, maka akan mengalami ketertinggalan yang sangat tinggi mulai dari pendapatan yang terus menurun, volume produk yang dijual tidak meningkat, dan masih banyak lagi ketertinggalanketertinggalan yang dihadapi karena kalah cepat dengan pengusaha lain yang telah memanfaatkan teknologi. Pemerintah juga mesti berperan aktif dalam mengawal perkembangan UMKM. Perubahan kondisi ekonomi warga khususnya pemilik usaha kecil mengalami peningkatan penjualan disebabkan oleh perluasan pasar yang dilakukan melaui pemanfaatan media sosial.

\section{KESIMPULAN}

Berdasarkan hasil pembahasan yang telah diuraikan dalam penelitian tersebut, maka dapat ditarik kesimpulan sebagai berikut:

1. Para pemilik usaha mikro dimasa pandemi terus menerus mengalami penurunan pendapatan.

2. Perlu adanya perubahan pola strategi pemasaran yang dilakukan melalui binaan kepada warga tersebut secara berkala, sehingga dapat diimplementasikan kemudian.

3. Perubahan pola strategi pemasaran sangat perlu untuk diberlakukan karena dapat berpengaruh secara tinggi terhadap pendapatan dan peningkatan penjualan produk UMKM.

\section{DAFTAR PUSTAKA}

Amri, A. (2020). Dampak Covid-19 Terhadap UMKM di Indonesia. Jurnal Brand, volume 2 No. 1.

Guru Pendidikan. (2020). Metode penelitian Kualitatif. Diambil Desember 10, 2020, dari https://www.gurupendidikan.co.id/

Hardilawati, W. L. (2020). Strategi Bertahan UMKM di Tengah Pandemi Covid-19. Jurnal Akuntansi \& Ekonomika, vol 10 No. 1.

Idris, "Panduan Cek Penerima BPUM UMKM BRI Via Eform”. Diambil Oktober 27, 2020, dari http://amp.kompas.com/money/read/2020/10/27/073519526/panduan-cekpenerima-bpum-umkm-bri-via-eform

Purwadi, D., \& Hidayat, N. (2016). Studi Kelayakan Bisnis. Depok: PT. Rajagrafindo Persada. 